\title{
Inclusive Policymaking Tools: A COVID-19 Pandemic Case Study
}

\section{Ans Irfan ${ }^{1}$, Ankita Arora ${ }^{2}$, Christopher Jackson ${ }^{3}$, Celina Valencia $^{4}$}

\author{
${ }^{1}$ Environmental and Occupational Health Department, Milken Institute School of Public Health, \\ George Washington University, Washington, D.C. \\ ${ }^{2}$ Department of Biochemistry and Molecular Genetics, University of Colorado-Anschutz Medical \\ Campus, Aurora, CO \\ 3Department of Chemistry, University of California, Berkeley, Berkeley, CA \\ ${ }^{4}$ Cancer Prevention and Control Program, The University of Arizona Cancer Center, Tucson, AZ \\ http://doi.org/10.38126/JSPG170112 \\ Corresponding author: ansirfan@gwu.edu
}

Keywords: diversity; equity; inclusion; DEI; inclusive public policy; COVID-19; social inequities; systems change; pandemic; community engagement; systems thinking; federal policy; public health

Executive Summary: World Health Organization (WHO) estimates indicate the United States of America has the highest novel Coronavirus disease (COVID-19) burden in the world, with over 5 million confirmed cases and nearly 165,000 associated deaths as of August 14th, 2020 (WHO 2020). As the COVID-19 mortality and morbidity has disproportionately impacted populations who experience vulnerabilities due to structural issues such as racism (Laurencin and McClinton 2020; Lin II and Money 2020; Martin 2020; Kim et al. 2020), it has become increasingly necessary to take this opportunity and intentionally codify diversity, equity, and inclusion (DEI) practices in the policymaking process. To encourage and facilitate this, we synthesize existing literature to identify best practices that can not only be used to inform COVID-19-related public policy activities but will also continue to inform inclusive policymaking processes in the future. We identify specific tools for policymakers at all levels of government to better operationalize the DEI framework and enact inclusive, equitable public policies as a result.

\section{Introduction}

The COVID-19 pandemic has exposed and exacerbated long-standing social inequities in the United States (U.S.), many of which can be directly tied to public policies that fail to consider the principles of diversity, equity, and inclusion (DEI). Sharing best practices and lessons learned can expedite sound policymaking and implementation processes. Evidence-based policies are based on relevant knowledge, research, and scientific evidence (de Marchi, Lucertini, and Tsoukiàs 2017). The benefits of the implementation of evidence-based policies have been captured across various sectors (Head 2015). The utility of a science-informed response to COVID-19 has been demonstrated in several cases during the COVID-19 pandemic, including in Germany (Kirschbaum and King 2020) and New Zealand (Cousins 2020). In both of these cases, an evidence-based approach requiring strict public health measures, occasionally unpopular with the public, led to better population health outcomes such as a decreased number of cases, case fatalities, and community-based infections. In fact, New Zealand became one of the first nations to be virusfree, thanks to its evidence-based approach to the pandemic.

However, it is not enough to ground policies in evidence alone. To achieve transformative social change and eliminate social inequities, it is equally 
important to ensure that policies are inclusive and represent the communities' views, values, and needs in an equitable way. Existing evidence, especially from applied research fields such as implementation sciences, emphasizes the critical importance of engaging with and accounting for different stakeholders for effective interventions and policies (Chambers 2020). One of the key approaches to ensuring effective interventions and public policies is to ensure policies are inclusive in nature starting at the development phase. This paper builds on previous work on evidence-based, inclusive policymaking and asserts that to maximize positive policy outcomes across all populations and timescales, we must expand on the evidence-based underpinning of public policies and incorporate a DEI framework in the policymaking process.

We use the COVID-19 pandemic, and subsequent government responses, as a case study to identify meaningful opportunities for policymakers at all levels of government to influence positive changes grounded in DEI during the pandemic. However, we also believe that the DEI framework presented here can serve as a long-term guiding principle for policymakers beyond the pandemic.

\section{Diversity, equity, and inclusion in policy}

Diversity, equity, and inclusion are three distinct but interconnected pillars that public policies aiming to be holistic and fair should address. The absence of a concerted effort to integrate DEI into the policymaking process has historically resulted in structural barriers that impede the equitable distribution of the benefits intended by policies. These social and structural barriers to an equitable society in public policy have enduring, multigenerational consequences (Krieger et al. 2020; McClure et al. 2019). The integration of a DEI framework in policies provides an opportunity to mitigate long-lasting repercussions experienced by individuals who have been historically left out by the public policymaking process. We posit that if inequitable public policies can create these structural barriers, inclusive policies can help dismantle these structural barriers and achieve a more fair and just society.

We operationalize the following definitions of diversity, equity, and inclusion in this paper (Bolger 2020). Briefly, "diversity" refers to differences in identities, including but not limited to race, gender, ethnicity, religion, political ideology, migration status, age, physical ability, and sexual orientation. Diversity can only exist in relationship to others, and the meaning of diversity can vary widely based on the situational context. It is about the recognition and appreciation of unique individual differences. "Equity" addresses the inherent disadvantages and barriers created by historical systems of oppressions such as racism to ensure fair access to the same opportunities. Equity is akin to providing a level playing field. Unlike diversity and inclusion, equity is a process, not an outcome. Finally, "inclusion" builds upon a diverse foundation, ensuring that diverse perspectives are not only present but valued and acted upon in a meaningful way that goes beyond performative actions. It is making a conscientious effort to welcome, involve, engage, and empower individuals with diverse characteristics in a process, including the policymaking process. Taken together, the incorporation of DEI principles in the policymaking process can have significant positive impacts leading to inclusive policies that are equitable and effective. Policymaking entities can benefit from an increased diversity of perspectives which results in better decisions, policy outcomes, and a just society (OECD 2015).

\section{Policy responses to COVID-19}

The ongoing COVID-19 pandemic has yet again exposed many of the inequitable social structures and public policy infrastructure that underlie U.S. society. Here, we offer examples from the business, education, and healthcare sectors to highlight the disproportionate impacts of the disease, economic fallout, and corresponding policy responses on Black, Indigenous, and other communities of color, and the necessity of a DEI framework.

\section{i. Business and employment}

The CARES Act, a $\$ 2$ trillion plus federal aid package passed in March of 2020 in response to the COVID-19 pandemic, highlights how well-meaning policies can be operationalized in ways that exacerbate social inequities. It also provides an opportunity to highlight the need for intentionally making an effort to formulate equitable policies. One subset of this package, the Paycheck Protection Program (PPP), exemplifies the disproportionate institutional burdens faced by minority-owned businesses. In PPP's early stages, the Small Business Administration 
(SBA) barred anyone with a criminal conviction in the past five years. This led to discrimination against members of the Black community who are often subjected to racially motivated higher rates of incarceration and convictions because of a racist legal system in the US (Donnan 2020). During the PPP program implementation, banks and lenders affiliated with the SBA also prioritized loans for their existing customers, which excluded many business owners of color (CRL 2020). This practice resulted in a projected $75-95 \%$ of Black, Latino, and Asian American/Pacific Islander (AAPI)-owned businesses having almost no chance of receiving a PPP loan (CRL 2020). By ensuring community voices are reflected at the early phases of policymaking, such unfortunate, structural injustices can be avoided.

At the individual level, while the COVID-19 driven recession is felt across the economy, the impact has not been equitably distributed (Cheng 2020; Badger and Parlapiano 2020). A study of San Francisco showed that the city's shelter-in-place ordinance caused COVID-19 cases to concentrate among lowincome Latinx communities, many of whom did not have the luxury, or proper occupational health protections, to work from home given the nature of their jobs as essential workers (Weiler 2020). At the same time, projections for a long-term shutdown in the U.S. estimate 42-54 million jobs that are vulnerable to reductions in hours or pay, temporary furloughs, or permanent layoffs. Of these, $42 \%$ are in service industries such as accommodation, food, and retail, highlighting disproportionate negative impacts among low-income workers and small businesses (Lund et al. 2020). Even as the economy recovers and jobs return, COVID-19 may further accelerate structural shifts in the economy towards an already increasing trend of gig economy - hiring independent workers for short-term commitments without benefits or many of the occupational health protections - or increased automation, changes that will require appropriate policy responses to ensure that historically marginalized communities are not left behind.

\section{ii. Education}

Other provisions of the CARES Act set aside $\$ 14$ billion for higher education, with funds intended to support low-income students and community colleges, which serve the majority of these students. However, for-profit schools (serving $5.4 \%$ of students) received $9 \%$ of funding, while community colleges (serving $32 \%$ of students) received just $22 \%$ (Seville and Lehren 2020). These disparities were created by a distribution formula that emphasizes full-time students with Pell grants, who are more likely to attend for-profit schools. Moreover, the Department of Education's guidelines explicitly discriminated against undocumented, international, and the Deferred Action for Childhood Arrivals recipients on the basis of migration status by limiting the eligibility criteria (Nadworny, 2020). This is yet another example of inequitable social structures that create opportunity gaps and turn education from the great equalizer of social mobility to the great stratifier.

The necessary transition to remote instruction has also had disproportionate negative impacts on underserved communities due to a lack of infrastructure and access and affordability of amenities like technology and high-speed internet. Even before COVID-19, studies estimated that the opportunity gap between white students and Black and Hispanic students cost the U.S. economy between $\$ 310$ to $\$ 525$ billion, with similar results for the gap between high-and low-income students (Dorn et al. 2020). New studies estimate that this learning loss will continue and be exacerbated for low-income, Black, and Hispanic students due to lower access or affordability to high-quality remote learning environments. Nationally, $20 \%$ of students don't have access to the technology they need for a conducive remote learning experience (Hobbs and Hawkins 2020). Strikingly, while $38 \%$ of white K-12 students are likely to receive average or above-average remote instruction, this percentage drops to $21 \%$ for Hispanic students and14\% for Black students (Dorn et al. 2020). These disparities result in months of lost learning, which leads to long-term socioeconomic implications. These short and long-term impacts can be avoided by having an inclusive approach. For instance, in response to the shortage of smart tablets, the Seoul Metropolitan Office of Education (SMOE) is operating a rental business that lends smart devices to students from low-income families to provide access to online education (Korea 2020). Policies like these, although still symptomatic treatment, ensure equal access to opportunities to learn for all, leading to an equitable education system. It is important to continue to challenge the systems such as poverty 
and racism that create such disparities in the first place.

\section{iii. Healthcare}

The dysfunctional U.S. healthcare system is illequipped to address the inequities exacerbated by COVID-19, leading to disparities in hospitalization rates, mortality, and morbidity among both children and adults (Ford, Reber \& Reeves, 2020; Kim et al. 2020). These disparities stem in part from lack of access or affordability to quality healthcare infrastructures. The mortality data from three dozen hospitals in New York revealed that patients at certain community hospitals were three times more likely to die than patients at private medical centers, a result of underfunding that led to lower staffing, worse equipment, and less access to treatment options (Rosennthal et al. 2020). Furthermore, when we consider healthcare workers who are being forced to risk their lives, due to a lack of occupational health protections, to care for patients, there remain significant systemic pay disparities across race, gender, and geography that must be addressed (Pifer 2020).

At the same time, a record number of layoffs has left millions of people without health insurance in the midst of a pandemic (Potter 2020). While the CARES Act requires all private plans to cover COVID-19 testing and future vaccines, it neglects those who are now unemployed or otherwise without access to insurance (Garfield, Claxton and Levitt 2020). In states where Medicaid has not been expanded, 3.1 million Americans still cannot afford health insurance; more than half of them are people of color, and $30 \%$ are Black (Yong 2020). Stopgap measures such as CARES act provisions are far from sufficient and only create an illusion of assistance. An inclusive approach to healthcare policy that goes beyond special interest and politicking is needed for a universal, equitable, and cost-effective healthcare system.

Policymakers must ensure that resource allocation priority is given to historically marginalized minority groups, particularly those who live in crowded conditions and have underlying medical conditions that increase their susceptibility to COVID-19 morbidity and mortality (Twohey 2020). For example, a CDC report recommended significant government action to tackle severe outbreaks among poultry plant workers, many of whom are Latinx and Marshallese, but failed to provide the necessary funds or an effort to collaborate with the Occupational Safety and Health Administration, the federal agency responsible for worker protections in the U.S. (Barrón-López and Ollstein, 2020). As treatment options and/or vaccines become available, it will require not only financial resources, but a sustained dialogue with all communities of color who have been historically overlooked or even harmed by the health care system to capture their unique needs and ensure equitable outcomes (Roubein and Owermohle, 2020).

These recent examples highlight both the importance and wide scope of impacts rooted in DEI considerations, as well as the negative consequences that can occur when DEI frameworks are not used in the policymaking process. Holistically, a DEI framework can lead to public policies with the potential for significant and equitable improvements in health, quality of life, and economic benefits to society.

\section{Inclusive policymaking recommendations}

The core of an inclusive policymaking process is the principle of open government across various levels federal, state, county, city, local - which ensures meaningful citizen engagement, transparency, and accountability. Here, we synthesize literature on existing best practices concerning inclusive policymaking and provide some recommendations and specific tools to assist with an inclusive policymaking process. We offer some broader themes for better operationalization of a DEI framework and provide a list of specific actions that can be taken to ensure policies are inclusive in nature (Appendix: Table 1; Figure 1).

\section{i. Positionality assessment}

As a person involved with the policymaking process, the first step towards establishing best practices for inclusive policymaking should be introspection and recognition of one's privileges, including but not limited to race, education, socioeconomic status, linguistic ability, immigration status, sex, gender, and sexual orientation. Far too often, scientists and policymakers develop policies based on their own assessments without acknowledging their blind spots or incorporating community needs and perspectives. Self-reflection to confront our biases and tools such as Project Implicit, for all its limitations, can be a good 
starting point (Project Implicit 2020). At this critical moment in U.S. history as we reckon with the endemic structural racism and increased xenophobia within the COVID-19 pandemic, the critical importance of positionality assessment, especially for those in a decision-making capacity, cannot be overstated. It is important to acknowledge that the policymaking process is not objective. Policymakers and policy advisors' beliefs, value systems, and morality are inseparable from the decisions they make, often underestimating the power dynamics and power differentials over communities those decisions are being made for. Being grounded in self reflexivity and intentionally assessing our positions in a policymaking capacity can lead to more informed, inclusive, and equitable policies.

\section{ii. Equity and impact assessment}

Experts developing policy must assess community needs and policy impacts that are grounded in the DEI framework. Moreover, policy proposals should make a concerted effort account for their impacts and unintended consequences on the populations who experience the most vulnerabilities. Impact assessments are an excellent tool for projecting the social, economic, environmental implications of a particular policy across the board. However, it is important to operationalize the impact assessments with a DEI approach that accounts for historical injustices towards certain historically marginalized populations and to ensure an equitable allocation of policy impacts. Similar to an impact assessment, an equity assessment will follow the same process with a focus on populations who experience the most vulnerabilities because of the interlocking systems of oppression and intentionally accounts for the exposure and impact differentials across vulnerable communities. In the case of COVID-19, these tools could have not only provided data on the consequences of the current response, but also generated evidence to inform similar emergency responses in the future.

\section{iii. Mainstreaming policymaking}

The policy community, particularly the science policy community, must collaborate with other sectors such as the news media to mainstream the policymaking process. Currently, most of the public is often unaware of the details of public policies being proposed, passed, and implemented across different levels of government. Policymakers should work to open and mainstream this process through collaborations with news and mass media and other tools such as social media. This mainstreaming process should include the use of plain language, instead of jargon, that is accessible to a larger audience outside of the public policy circuits. By educating and informing the public about the policymaking process, scientists and policymakers will ensure broader participation in the process and eventual inclusive policy as a result of such participation.

\section{iv. Community engagement}

Meaningful community engagement is critical to an inclusive policymaking and development process. It is of paramount importance to ensure we engage local communities, particularly communities that experience vulnerabilities, in a tangible, meaningful way. For any given policy, it is crucial to identify stakeholders who may be either unable or unwilling to participate in the policymaking process. Policymakers should do the due diligence for aggressive outreach to these groups and incentivize participation to ensure their views, unique set of needs, and challenges are reflected in the final policy. A collaborative, community-centered approach towards public policy is the key towards positive social change and dismantling persistent challenges such as racism. Disparities in COVID-19 mortality and morbidity (Ford, Reber \& Reeves, 2020) are reflective of a lack of community engagement in the policymaking process that leaves unmet needs and gaps in public policies, resulting in significant damage to communities. Engaging communities and getting their feedback can result in effective and inclusive policies that strengthen societies.

\section{v. Citizen e-consultation}

Building off the need for community engagement, it is critical to acknowledge that despite living in the digital era, policymaking process has largely lagged in taking full advantage of tools that can assist in community engagement and result in inclusive policies. $90 \%$ of the U.S. adult population uses the internet (Clement 2020). It is important to take advantage of this valuable resource and reach vulnerable communities through the internet in ways that are equitable and accessible. "E-consultation" is defined as using information and communication 
technologies (ICT) to support a collaboration in which citizens contribute their views and opinions to the government (Blumler and Coleman 2001). Various ICTs that could be used for community input in the policymaking process include the internet and email, smartphones, interactive digital television

(DiTV), and video conferencing, and so on. COVID-19 pandemic and physical distancing requirements have further highlighted the utility of making econsultation a key component of policymaking feedback solicitation for inclusive policies. As an example, ICTs played a vital role in fighting COVID-19 in South Korea (Korea 2020). Free smartphone apps were used to support early detection, contact tracing, and to flag infection hotspots and an upsurge in local cases, providing critical data to combat the virus' spread (Korea 2020).

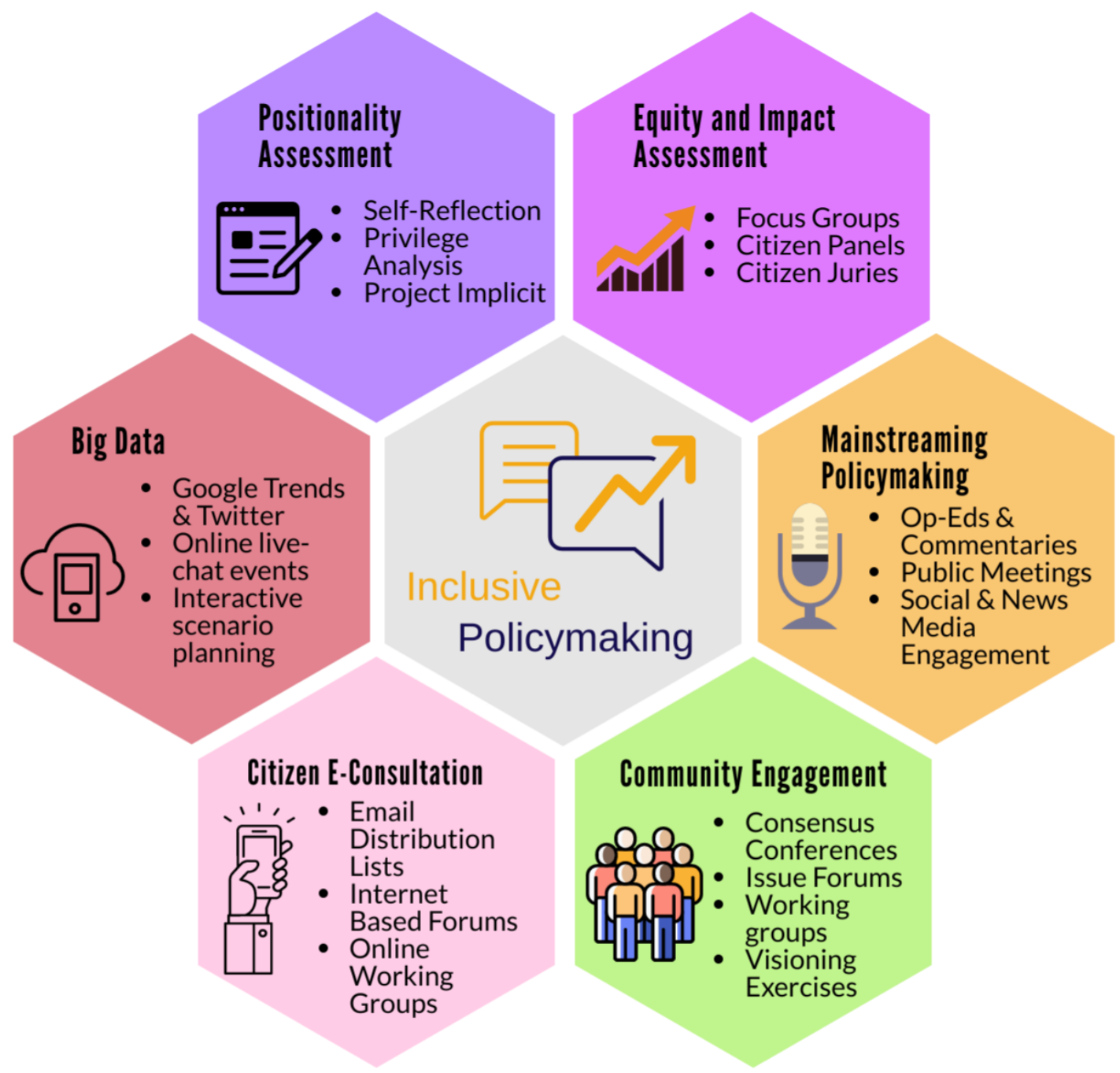

Figure 1: Inclusive policymaking recommendations and tools.

\section{vi. Big data}

Utilizing big data can provide rapid insights into community realities while also providing opportunity to bridge the gap between population level needs and public policies. An example of big data's potential for response is the COVID-19 High Performance Computing (HPC) Consortium with mass computing capacity to keep pace with the vast emerging data on the virus (Dabbar, 2020). While demographic data is currently only available for less than $50 \%$ of COVID19 cases, better data collection and use could lead to more inclusive response legislation during a constantly evolving crisis (CDC 2020). The rapid, large-scale availability of relevant information can help protect the most excluded individuals against further regressions through equitable, early-stage 
policy decisions. Specific examples include Google Trends and Twitter.

Within the Twitterverse, notable groups such as Black Twitter could provide useful insights into public opinion trends and needs specific to the Black community, for instance. It is important to note that these insights may have some degree of bias as the users are self-selecting to engage in these platforms, have the technical capabilities, access, and affordability, hence, the insights may not be reflective of the entire community's views. Nonetheless, big data provides an opportunity for data points to be collected from populations and communities that are historically underrepresented in traditional datasets. Moreover, as big data diverges from other types of data as it is often collected passively and shifts the burden away from individuals. This allows for more encompassing data points that can then be used for informing public policies.

\section{Conclusion}

The COVID-19 pandemic has exacerbated many structural inequities, intended or unintended, and highlighted the urgent need to integrate DEI practices into the U.S. policymaking process. The pandemic's ripple effects have been felt broadly across multiple sectors, with disproportionately negative impacts on low-income and otherwise historically marginalized communities. Here, we present a broad range of DEI tools for inclusive policymaking ranging from selfassessment to community engagement to effective use of big data. Although we use COVID-19 as the case study, these tools will continue to assist policymakers and advisors in ensuring that future public policies are inclusive across the board and focused on not only alleviating the effects of structural issues such as racism but also actively dismantle such systems.

\section{Appendix A: Table 1: Inclusive Policymaking Tools}

\begin{tabular}{|c|c|c|c|c|c|}
\hline \multirow{2}{*}{$\begin{array}{c}\text { Inclusive } \\
\text { Policymaking } \\
\text { Tool }\end{array}$} & \multirow[t]{2}{*}{ Brief Description } & \multirow[t]{2}{*}{ Strengths } & \multirow[t]{2}{*}{$\begin{array}{c}\text { Recommendation } \\
\text { Class }\end{array}$} & \multicolumn{2}{|c|}{$\begin{array}{c}\text { Resource } \\
\text { Intensiveness } \\
\text { Index* }\end{array}$} \\
\hline & & & & Time & Logistic \\
\hline Citizen Juries & $\begin{array}{l}\text { A group of } 12-16 \\
\text { citizens recruited to } \\
\text { best represent a } \\
\text { population are } \\
\text { brought } \\
\text { together to discuss a } \\
\text { policy issue. Juries last } \\
\text { for up to four days and } \\
\text { utilize independent } \\
\text { facilitators. Their } \\
\text { conclusions are then } \\
\text { compiled in a report } \\
\text { to be presented to the } \\
\text { commissioning body, } \\
\text { such as a policymaker. }\end{array}$ & $\begin{array}{l}\text { Developing } \\
\text { creative and } \\
\text { innovative } \\
\text { solutions to } \\
\text { difficult } \\
\text { problems with } \\
\text { expert opinions } \\
\text { and soliciting } \\
\text { deeper } \\
\text { contextual } \\
\text { understanding of } \\
\text { community } \\
\text { needs }\end{array}$ & $\begin{array}{l}\text { Equity and Impact } \\
\text { Assessment } \\
\text { Community } \\
\text { Engagement }\end{array}$ & Medium & High \\
\hline
\end{tabular}




\begin{tabular}{|c|c|c|c|c|c|}
\hline Citizen Panels & $\begin{array}{l}\text { These standing panels } \\
\text { are made up of a } \\
\text { representative sample } \\
\text { of the population } \\
(\sim 500-5,000 \text { people }) \text {. } \\
\text { The views of panel } \\
\text { members on different } \\
\text { issues are sought } \\
\text { regularly using a } \\
\text { variety of methods, } \\
\text { such as surveys, } \\
\text { interviews or focus } \\
\text { groups. }\end{array}$ & $\begin{array}{l}\text { Panels are cost } \\
\text { effective once } \\
\text { initial set up is } \\
\text { done and can be } \\
\text { used flexibly. } \\
\text { However, } \\
\text { attrition can be a } \\
\text { problem, as it } \\
\text { affects the } \\
\text { representativene } \\
\text { ss of the panel. }\end{array}$ & $\begin{array}{l}\text { Mainstreaming } \\
\text { Policymaking } \\
\text { Citizen E- } \\
\text { Consultation }\end{array}$ & Medium & Medium \\
\hline $\begin{array}{l}\text { Consensus } \\
\text { Conferences }\end{array}$ & $\begin{array}{l}\text { A panel of } 15-20 \\
\text { people representing } \\
\text { all of the communities } \\
\text { who will be impacted } \\
\text { by the proposed } \\
\text { policy are recruited } \\
\text { through random } \\
\text { selection techniques. } \\
\text { The aim is to develop } \\
\text { an understanding of a } \\
\text { specific topic through } \\
\text { briefing materials and } \\
\text { dialogue with experts. }\end{array}$ & $\begin{array}{l}\text { Opens } \\
\text { policymaking to } \\
\text { direct public } \\
\text { scrutiny with } \\
\text { access to experts } \\
\text { in the respective } \\
\text { fields. Initial set- } \\
\text { up is demanding } \\
\text { but easily } \\
\text { scalable. }\end{array}$ & $\begin{array}{l}\text { Community } \\
\text { Engagement }\end{array}$ & High & High \\
\hline $\begin{array}{l}\text { Electronic } \\
\text { Letterboxes }\end{array}$ & $\begin{array}{l}\text { Email addresses on } \\
\text { websites or } \\
\text { documents which give } \\
\text { citizens opportunities } \\
\text { to give feedback to the } \\
\text { government. }\end{array}$ & $\begin{array}{l}\text { Low-cost, easy to } \\
\text { implement and } \\
\text { engage larger } \\
\text { audiences. }\end{array}$ & $\begin{array}{l}\text { Equity \& Impact } \\
\text { Assessment }\end{array}$ & Low & Medium \\
\hline $\begin{array}{l}\text { Email } \\
\text { Distribution } \\
\text { Lists }\end{array}$ & $\begin{array}{l}\text { Lists used to circulate } \\
\text { consultation } \\
\text { documents to } \\
\text { interested parties. } \\
\text { Citizens can register } \\
\text { for these lists via a } \\
\text { website. Their } \\
\text { comments are } \\
\text { forwarded to the } \\
\text { government. }\end{array}$ & $\begin{array}{l}\text { Higher } \\
\text { participation, but } \\
\text { requires efforts } \\
\text { to skim through } \\
\text { the comments. }\end{array}$ & $\begin{array}{l}\text { Equity \& Impact } \\
\text { Assessment }\end{array}$ & Low & Low \\
\hline
\end{tabular}




\begin{tabular}{|c|c|c|c|c|c|}
\hline Focus Groups & $\begin{array}{l}\text { Focus groups bring } \\
\text { together 8-10 } \\
\text { community } \\
\text { representatives, led by } \\
\text { a trained facilitator to } \\
\text { discuss a particular } \\
\text { issue. Information can } \\
\text { be provided, but the } \\
\text { purpose is to explore } \\
\text { opinions and needs of } \\
\text { a particular } \\
\text { community in depth. } \\
\text { Moreover, asking } \\
\text { open-ended questions } \\
\text { about the potential } \\
\text { impact on their } \\
\text { communities can help } \\
\text { alleviate negative or } \\
\text { unintended } \\
\text { consequences of a } \\
\text { policy proposal. }\end{array}$ & $\begin{array}{l}\text { Gives in-depth } \\
\text { insight into a } \\
\text { specific issue and } \\
\text { the contextual } \\
\text { and or situational } \\
\text { factors that may } \\
\text { not be captured } \\
\text { by quantitative } \\
\text { data such as } \\
\text { surveys. }\end{array}$ & $\begin{array}{l}\text { Community } \\
\text { Engagement } \\
\text { Equity and Impact } \\
\text { Assessment }\end{array}$ & Medium & Medium \\
\hline $\begin{array}{l}\text { Google Trends } \\
\text { \& Twitter }\end{array}$ & $\begin{array}{l}\text { These tools can } \\
\text { provide useful insights } \\
\text { into public opinions, } \\
\text { needs, and policy gaps } \\
\text { in an efficient, rapid, } \\
\text { and low-cost manner. }\end{array}$ & $\begin{array}{l}\text { Extremely useful } \\
\text { for emergency } \\
\text { and rapid policy } \\
\text { development } \\
\text { needs. }\end{array}$ & Big Data & Low & Low \\
\hline $\begin{array}{l}\text { Interactive } \\
\text { Scenario } \\
\text { Planning }\end{array}$ & $\begin{array}{l}\text { This tool can be used } \\
\text { to engage citizens in } \\
\text { developing policy } \\
\text { options or proposals. }\end{array}$ & $\begin{array}{l}\text { Increases public } \\
\text { interest in policy } \\
\text { by making it } \\
\text { more engaging. }\end{array}$ & $\begin{array}{l}\text { Mainstreaming } \\
\text { policymaking } \\
\text { Community } \\
\text { Engagement } \\
\text { Big Data }\end{array}$ & Medium & High \\
\hline $\begin{array}{l}\text { Internet- based } \\
\text { Forums }\end{array}$ & $\begin{array}{l}\text { These can be limited } \\
\text { to certain individuals } \\
\text { (e.g. stakeholders) or } \\
\text { open to anyone. These } \\
\text { can be designed to } \\
\text { allow citizens to: } \\
\text { respond to } \\
\text { government proposals } \\
\text { on-line; read and view } \\
\text { the comments of all } \\
\text { participants, and } \\
\text { engage with other }\end{array}$ & $\begin{array}{l}\text { Provides } \\
\text { opportunities to } \\
\text { have an ongoing } \\
\text { dialogue with the } \\
\text { public on } \\
\text { particular issues } \\
\text { to help formulate } \\
\text { policies. }\end{array}$ & $\begin{array}{l}\text { Mainstreaming } \\
\text { Policymaking } \\
\text { Community } \\
\text { Engagement } \\
\text { Citizen E- } \\
\text { consultation }\end{array}$ & Low & Low \\
\hline
\end{tabular}




\begin{tabular}{|c|c|c|c|c|c|}
\hline & $\begin{array}{l}\text { citizens in a dialogue } \\
\text { on the proposals. }\end{array}$ & & & & \\
\hline Issue Forums & $\begin{array}{l}\text { These are ongoing } \\
\text { bodies with regular } \\
\text { meetings that focus on } \\
\text { a particular issue. } \\
\text { They may have a set } \\
\text { membership or } \\
\text { operate on an open } \\
\text { basis. }\end{array}$ & $\begin{array}{l}\text { Provides } \\
\text { opportunities to } \\
\text { have an ongoing } \\
\text { dialogue with the } \\
\text { public on } \\
\text { particular issues } \\
\text { to help formulate } \\
\text { policies. }\end{array}$ & $\begin{array}{l}\text { Community } \\
\text { Engagement }\end{array}$ & Medium & High \\
\hline $\begin{array}{l}\text { On-line Live } \\
\text { Chat Events }\end{array}$ & $\begin{array}{l}\text { Participants exchange } \\
\text { views, within a fixed } \\
\text { period of time (usually } \\
2 \text { hours), with } \\
\text { government leaders. } \\
\text { These can take place } \\
\text { during the time period } \\
\text { of an internet } \\
\text { discussion forum or } \\
\text { separately. }\end{array}$ & $\begin{array}{l}\text { Dissemination of } \\
\text { information and } \\
\text { answering public } \\
\text { queries. }\end{array}$ & $\begin{array}{l}\text { Citizen E- } \\
\text { consultation } \\
\text { Big Data }\end{array}$ & Low & Low \\
\hline $\begin{array}{l}\text { Op-Eds \& } \\
\text { Commentaries }\end{array}$ & $\begin{array}{l}\text { These tools in local } \\
\text { and/or national } \\
\text { outlets represent } \\
\text { strong, informed, and } \\
\text { focused opinions of an } \\
\text { independent writer on } \\
\text { an issue of relevance } \\
\text { to a targeted audience. }\end{array}$ & $\begin{array}{l}\text { Disseminating } \\
\text { the information } \\
\text { to public on } \\
\text { policy proposals } \\
\text { in digestible } \\
\text { chunks and help } \\
\text { mainstream the } \\
\text { policymaking } \\
\text { process. }\end{array}$ & $\begin{array}{l}\text { Mainstreaming } \\
\text { Policymaking }\end{array}$ & Low & Low \\
\hline $\begin{array}{l}\text { Planning for } \\
\text { Real }\end{array}$ & $\begin{array}{l}\text { Often initiated by local } \\
\text { communities for } \\
\text { planning issues, a } \\
\text { three-dimensional } \\
\text { model of a particular } \\
\text { neighborhood is } \\
\text { created. At a public } \\
\text { event displaying this } \\
\text { model, the public is } \\
\text { invited to attach cards } \\
\text { to identify problems, } \\
\text { areas of concern, and } \\
\text { possible solutions. }\end{array}$ & $\begin{array}{l}\text { This technique's } \\
\text { emphasis on } \\
\text { visual materials } \\
\text { encourages a } \\
\text { range of people } \\
\text { to participate in } \\
\text { the events. }\end{array}$ & $\begin{array}{l}\text { Equity \& Impact } \\
\text { Assessment }\end{array}$ & Medium & Medium \\
\hline
\end{tabular}




\begin{tabular}{|c|c|c|c|c|c|}
\hline $\begin{array}{l}\text { Privilege } \\
\text { Analysis }\end{array}$ & $\begin{array}{l}\text { Reflecting on one's } \\
\text { privileges, - e.g., } \\
\text { education, age, sex, } \\
\text { race, language, } \\
\text { migration status, and } \\
\text { so on - and societal } \\
\text { advantages can help a } \\
\text { policymaker or policy } \\
\text { advisor to have a } \\
\text { broader } \\
\text { understanding of the } \\
\text { issues. With some } \\
\text { reflection and } \\
\text { accounting for their } \\
\text { privileges, they are } \\
\text { able to proceed with } \\
\text { humility and account } \\
\text { for their blindspots } \\
\text { and approach } \\
\text { policymaking with a } \\
\text { more just approach. }\end{array}$ & $\begin{array}{l}\text { Great starting } \\
\text { point towards } \\
\text { making an } \\
\text { attempt at } \\
\text { avoiding any } \\
\text { pitfalls and } \\
\text { unintended } \\
\text { consequences of } \\
\text { a proposed } \\
\text { policy. }\end{array}$ & $\begin{array}{l}\text { Positionality } \\
\text { Assessment }\end{array}$ & Medium & Low \\
\hline Project Implicit & $\begin{array}{l}\text { This tool provides } \\
\text { some insights into the } \\
\text { implicit biases that } \\
\text { one may have towards } \\
\text { a group. The results } \\
\text { are more accurate in } \\
\text { the aggregate form } \\
\text { and it has its caveats, } \\
\text { but it can be good at } \\
\text { providing some } \\
\text { insights into } \\
\text { unconscious biases. }\end{array}$ & $\begin{array}{l}\text { Helps obtain } \\
\text { some insights } \\
\text { into unconscious, } \\
\text { implicit biases so } \\
\text { one can be more } \\
\text { self-reflective } \\
\text { and conscious } \\
\text { when } \\
\text { approaching a } \\
\text { policy position. }\end{array}$ & $\begin{array}{l}\text { Positionality } \\
\text { Assessment }\end{array}$ & Low & Low \\
\hline Public Meetings & $\begin{array}{l}\text { An open invitation is } \\
\text { extended to any } \\
\text { member of the public } \\
\text { (e.g. through } \\
\text { advertising) to learn } \\
\text { about an issue. The } \\
\text { public policy } \\
\text { organizers present } \\
\text { information and } \\
\text { encourage healthy } \\
\text { dialogue on issues } \\
\text { raised by the } \\
\text { audience. }\end{array}$ & $\begin{array}{l}\text { Demonstrates a } \\
\text { transparent and } \\
\text { open approach to } \\
\text { policymaking. }\end{array}$ & $\begin{array}{l}\text { Community } \\
\text { Engagement } \\
\text { Mainstreaming } \\
\text { policy }\end{array}$ & Medium & Medium \\
\hline
\end{tabular}




\begin{tabular}{|c|c|c|c|c|c|}
\hline $\begin{array}{l}\text { Questionnaires } \\
\text { with Equitable } \\
\text { Outreach }\end{array}$ & $\begin{array}{l}\text { A representative } \\
\text { sample of the public, } \\
\text { with a focus on } \\
\text { underrepresented } \\
\text { minority communities } \\
\text { through techniques } \\
\text { such as oversampling, } \\
\text { are asked a set of } \\
\text { questions; their } \\
\text { responses are } \\
\text { collected and } \\
\text { analyzed. }\end{array}$ & $\begin{array}{l}\text { Finding out the } \\
\text { opinions on } \\
\text { particular issues } \\
\text { as part of a } \\
\text { public } \\
\text { consultation } \\
\text { exercise. }\end{array}$ & $\begin{array}{l}\text { Community } \\
\text { Engagement } \\
\text { Citizen E- } \\
\text { consultation } \\
\text { Equity \& Impact } \\
\text { Assessment }\end{array}$ & Low & Medium \\
\hline $\begin{array}{l}\text { Re- convening } \\
\text { Groups }\end{array}$ & $\begin{array}{l}\text { The participants are } \\
\text { invited to reconvene } \\
\text { as a group on one or } \\
\text { multiple occasions, } \\
\text { having had time to } \\
\text { read information, } \\
\text { debate, gain feedback } \\
\text { from their respective } \\
\text { communities, and } \\
\text { refine their views. } \\
\text { These groups often } \\
\text { meet for up to two } \\
\text { hours, allowing for a } \\
\text { more } \\
\text { in-depth discussion } \\
\text { than focus groups and } \\
\text { resulting in } \\
\text { consensus- based } \\
\text { public policies. }\end{array}$ & $\begin{array}{l}\text { Engaging } \\
\text { participants to } \\
\text { continue their } \\
\text { discussion and } \\
\text { introspection } \\
\text { between } \\
\text { meetings and } \\
\text { gaining fresh } \\
\text { insights from the } \\
\text { communities } \\
\text { represented by } \\
\text { the group } \\
\text { members }\end{array}$ & $\begin{array}{l}\text { Community } \\
\text { Engagement } \\
\text { Positionality } \\
\text { Assessment }\end{array}$ & Medium & Medium \\
\hline Self- Reflection & $\begin{array}{l}\text { These can take the } \\
\text { form of a brief journal. } \\
\text { The conceptual idea is } \\
\text { to provide oneself } \\
\text { some space to reflect } \\
\text { on their social } \\
\text { position within } \\
\text { society and make an } \\
\text { earnest attempt at } \\
\text { reflecting on their } \\
\text { blind spots before } \\
\text { starting a } \\
\text { policymaking process. }\end{array}$ & $\begin{array}{l}\text { Provide useful } \\
\text { reflections on } \\
\text { one's } \\
\text { positionality and } \\
\text { status within the } \\
\text { socio- ecological } \\
\text { framework and, } \\
\text { ideally, would } \\
\text { result in public } \\
\text { policy leaders } \\
\text { leading with } \\
\text { humility and a } \\
\text { better } \\
\text { understanding of } \\
\text { equity-based } \\
\text { approaches. }\end{array}$ & $\begin{array}{l}\text { Positionality } \\
\text { Assessment }\end{array}$ & Medium & Low \\
\hline
\end{tabular}




\begin{tabular}{|c|c|c|c|c|c|}
\hline $\begin{array}{l}\text { Social \& News } \\
\text { Media } \\
\text { Engagement }\end{array}$ & $\begin{array}{l}\text { Engaging social and } \\
\text { news media through } \\
\text { articles, podcasts, } \\
\text { cable and radio news } \\
\text { show appearances. } \\
\text { should be an } \\
\text { important component } \\
\text { of the public } \\
\text { policymaking process. }\end{array}$ & $\begin{array}{l}\text { These tools such } \\
\text { as Twitter, } \\
\text { Instagram, } \\
\text { SnapChat, are } \\
\text { also critical to } \\
\text { mainstreaming } \\
\text { the public } \\
\text { policymaking } \\
\text { process. }\end{array}$ & $\begin{array}{l}\text { Mainstreaming } \\
\text { Policymaking }\end{array}$ & Low & Low \\
\hline $\begin{array}{l}\text { Visioning } \\
\text { Exercises }\end{array}$ & $\begin{array}{l}\text { This brings together a } \\
\text { large group of } \\
\text { stakeholders }(\sim 60) \text {, } \\
\text { selected because they } \\
\text { have decision-making } \\
\text { authority, and } \\
\text { understanding of, or } \\
\text { are affected by, the } \\
\text { topic under } \\
\text { discussion. } \\
\text { Participants take part } \\
\text { in a structured } \\
\text { meeting, lasting up to } \\
\text { two and a half days, } \\
\text { where they develop a } \\
\text { shared vision for the } \\
\text { future and commit to } \\
\text { action towards the } \\
\text { vision. }\end{array}$ & $\begin{array}{l}\text { Good for helping } \\
\text { to create } \\
\text { consensus } \\
\text { amongst a range } \\
\text { of different } \\
\text { stakeholders. }\end{array}$ & $\begin{array}{l}\text { Positionality } \\
\text { Assessment } \\
\text { Community } \\
\text { Engagement }\end{array}$ & Medium & Medium \\
\hline $\begin{array}{l}\text { Working } \\
\text { Groups }\end{array}$ & $\begin{array}{l}\text { Working groups can } \\
\text { likely be composed of } \\
\text { the following groups } \\
\text { in developing a } \\
\text { specific policy: } \\
\text { experts, citizens, } \\
\text { representatives of } \\
\text { civil society groups, } \\
\text { and government } \\
\text { officials. They might } \\
\text { serve as a consultative } \\
\text { forum or charged with } \\
\text { engaging different } \\
\text { groups and } \\
\text { individuals in } \\
\text { policymaking. These } \\
\text { can also be convened } \\
\text { online through Zoom } \\
\text { or other similar } \\
\text { technologies. }\end{array}$ & $\begin{array}{l}\text { Good for drawing } \\
\text { on the expertise } \\
\text { of a range of } \\
\text { people to help } \\
\text { develop policy. }\end{array}$ & $\begin{array}{l}\text { Community } \\
\text { Engagement } \\
\text { Citizen E- } \\
\text { consultation }\end{array}$ & Medium & High \\
\hline
\end{tabular}




\begin{tabular}{|c|c|c|c|c|c|}
\hline Workshops & $\begin{array}{l}\text { These allow } \\
\text { policymakers to } \\
\text { engage in a dialogue } \\
\text { with a group of } \\
\text { citizens or } \\
\text { stakeholders on a } \\
\text { specific issue. The } \\
\text { policymaking entity } \\
\text { may introduce the } \\
\text { issue for discussion } \\
\text { and invite participants } \\
\text { to debate in a mixture } \\
\text { of small group and } \\
\text { plenary sessions. They } \\
\text { usually last between } \\
\text { range in length from a } \\
\text { half to -to-two full } \\
\text { days. }\end{array}$ & $\begin{array}{l}\text { Good for } \\
\text { providing } \\
\text { opportunities to } \\
\text { assess an issue in } \\
\text { some depth } \\
\text { covering various } \\
\text { aspects such as } \\
\text { problems, policy } \\
\text { priorities and } \\
\text { solutions. }\end{array}$ & $\begin{array}{l}\text { Community } \\
\text { Engagement }\end{array}$ & Medium & High \\
\hline $\begin{array}{l}\text { Written } \\
\text { Consultation } \\
\text { Exercises }\end{array}$ & $\begin{array}{l}\text { The public } \\
\text { participates in giving } \\
\text { feedback and } \\
\text { comments on policies } \\
\text { laid out in a document. }\end{array}$ & $\begin{array}{l}\text { Good for } \\
\text { collating views } \\
\text { from diverse } \\
\text { parties on } \\
\text { detailed and } \\
\text { potentially } \\
\text { complex } \\
\text { proposals. }\end{array}$ & $\begin{array}{l}\text { Community } \\
\text { Engagement }\end{array}$ & Low & Medium \\
\hline
\end{tabular}

*Resource intensiveness is defined by the time required to implement the strategy and logistical feasibility with a qualitative rating of low, medium, and high.

\section{References}

Badger, Emily, and Alicia Parlapiano. 2020. "The Rich Cut Their Spending. That Has Hurt All the Workers Who Count on It". The New York Times. https://www.nytimes.com/2020/06/17/upshot /coronavirus-spending-rich-poor.html

Barrón-López, Laura, and Alice Miranda Ollstein. 2020. “Trump's fragmented pandemic response may undermine push to address racial disparities". Politico. https://www.politico.com/news/2020/07/26/c dc-pandemic-response-racial-disparities-381416

BBC News. (2020). New Zealand lifts COVID restrictions as virus cases hit zero. Retrieved July 25th 2020 , from https://www.bbc.com/news/world-asia$\underline{52961539}$

Blumler, Jay, and Stephen Coleman. 2001. "Realising Democracy Online: A Civic Commons In Cyberspace."
Bolger, Meg. 2020. "Diversity, Inclusion \& Equity In Tech: Understand The Difference". General Assembly Blog. https://generalassemb.ly/blog/diversityinclusion-equity-differences-in-meaning/.

Cabinet Office. 2002. "Viewfinder: A Policy Maker's Guide To Public Involvement". https://www.portlandoregon.gov/civic/article/8 4452.

CDC. 2020. "Demographic Trends of COVID-19 cases and deaths in the US reported to the CDC". https://www.cdc.gov/covid-datatracker/index.html\#demographics

Chambers, David A. 2020. "Considering The Intersection Between Implementation Science And COVID19". Implementation Research And Practice : 002076402092599. doi:10.1177/0020764020925994.

Cheng, Michelle. 2020. "U.S. unemployment fell in May-but not for Black people". Quartz. https://qz.com/1865348/us-unemployment-fellin-may-but-not-for-black-people/ 
Clement, J. 2020. "Topic: Internet Usage In The United States". Statista. https://www.statista.com/topics/2237/internetusage-in-the-united-states/.

Cousins, Sophie. 2020. "New Zealand Eliminates COVID19". The Lancet 395 (10235): 1474. https://doi.org/10.1016/S0140-6736(20)31097$\underline{7}$

CRL. 2020. "The Paycheck Protection Program Continues To Be Disadvantageous To Smaller Businesses, Especially Businesses Owned By People Of Color And The Self-Employed". Center for Responsible Lending.

Dabbar, P. (2020). Running with the Speed of Science in the Race Against COVID-19. Retrieved July 24th 2020, from https://www.energy.gov/articles/runningspeed-science-race-against-covid-19

De Marchi, Giada, Giulia Lucertini, and Alexis Tsoukiàs. 2017. "From Evidence-Based Policy-Making To Policy Analytics."

Donnan, Shawn. 2020. "Black Neighborhoods Miss Out on Stimulus and Fall Further Behind". Bloomberg Businessweek. https://www.bloomberg.com/news/features/20 20-07-15/america-s-2-trillion-rescue-leavesblack-neighborhood-behind.

Dorn, Emma, Bryan Hancock, Jimmy Sarakatsannis, and Ellen Viruleg. 2020. "COVID-19 and student learning in the United States: The hurt could last a lifetime". McKinsey \& Company. https://www.mckinsey.com/industries/publicsector/our-insights/covid-19-and-studentlearning-in-the-united-states-the-hurt-could-lasta-lifetime

Ford, T., Reber, S., \& Reeves, R. (2020). Race gaps in COVID-19 deaths are even bigger than they appear. Retrieved July 24th 2020, from https://www.brookings.edu/blog/upfront/2020/06/16/race-gaps-in-covid-19deaths-are-even-bigger-than-they-appear/

Garfield, Rachel, Gary Claxton, and Larry Levitt. 2020. "Eligibility For ACA Health Coverage Following Job Loss". KFF. https://www.kff.org/coronaviruscovid-19/issue-brief/eligibility-for-aca-healthcoverage-following-job-loss/.

Head, Brian W. 2015. "Toward More "Evidence-Informed" Policy Making?". Public Administration Review 76 (3): 472-484. https://doi:10.1111/puar.12475.

Hobbs, Tawnell D. and Lee Hawkins. "The Results Are In for Remote Learning: It Didn't Work". The Wall Street Journal. https://www.wsj.com/articles/schoolscoronavirus-remote-learning-lockdown-tech$\underline{11591375078}$
Kim, Lindsay, Michael Whitaker, Alissa O'Halloran et al. "Hospital Rates and Characteristics of Children Aged $<18$ Years Hospitalized with LaboratoryConfirmed COVID-19 - COVID-NET, 14 States, March 1-July 25, 2020. https://doi:10.15585/mmwr.mm6932e3.

Kirschbaum, Erik, and Laura King. 2020. "Germany Avoids The Worst of Coronavirus Crisis - But How?". Los Angeles Times.

https://www.latimes.com/worldnation/story/2020-04-29/there-are-reasonsgermany-stands-out-as-a-european-leader-thistime-during-the-coronavirus-scare.

Krieger, Nancy, Emily Wright, Jarvis T Chen, Pamela D Waterman, Eric R Huntley, and Mariana Arcaya. 2020. "Cancer Stage At Diagnosis, Historical Redlining, And Current Neighborhood Characteristics: Breast, Cervical, Lung, And Colorectal Cancer, Massachusetts, 2001-2015". American Journal Of Epidemiology. https://doi:10.1093/aje/kwaa045.

Korea. (2020). Flattening the curve on COVID-19 | Consulate General of the Republic of Korea in Houston. Retrieved July 24th 2020, from http://overseas.mofa.go.kr/us-houstonen/brd/m 5573/view.do?seq=759765

Laurencin, Cato T., and Aneesah McClinton. 2020. "The COVID-19 Pandemic: A Call To Action To Identify And Address Racial And Ethnic Disparities". Journal Of Racial And Ethnic Health Disparities 7 (3): 398-402. https://doi:10.1007/s40615-02000756-0.

Lin II, Rong-Gong, and Luke Money. 2020. "The Two Big Reasons Why California Is Struggling To Control Coronavirus". Los Angeles Times. https://www.latimes.com/california/story/2020 -05-13/two-big-reasons-california-has-struggledto-control-coronavirus.

Lund, Susan, Kweilin Ellingrud, Bryan Hancock, James Manyika, and André Dua. 2020. "Lives and livelihoods: Assessing the near-term impact of COVID-19 on U.S. workers". McKinsey \& Company. https://www.mckinsey.com/industries/publicsector/our-insights/lives-and-livelihoodsassessing-the-near-term-impact-of-covid-19-onus-workers

Martin, Rachel. 2020. "Navajo Nation President Says COVID-19 Has Killed 103". Npr.Org. https://www.npr.org/sections/coronavirus-liveupdates/2020/05/13/855419230/navajonation-president-says-covid-19-has-killed-103. 
McClure, Elizabeth, Lydia Feinstein, Evette Cordoba, Christian Douglas, Michael Emch, Whitney Robinson, Sandro Galea, and Allison E. Aiello. 2019. "The Legacy Of Redlining In The Effect of Foreclosures On Detroit Residents' Self-Rated Health". Health \& Place 55: 9-19. https://doi:10.1016/j.healthplace.2018.10.004.

Nadworny, E. (2020). Congress Gave Colleges A \$14 Billion Lifeline. Here's Where It's Going. Npr.org. Retrieved 18 August 2020, from https://www.npr.org/2020/05/18/853788067/ congress-gave-colleges-a-14-billion-lifelineheres-where-it-s-going.

NLC. 2020. "National League Of Cities | Cities Strong Together". Nlc.Org. https://www.nlc.org/.

OECD. 2015. Inclusive government for a more inclusive society, https://www.oecdilibrary.org/content/component/gov glance2015-6-en.

Pifer, Rebecca. 2020. "Front-Line COVID-19 Responders In Middle Of Pack On Pay". Healthcare Dive. https://www.healthcaredive.com/news/doctorpay-compensation-covid-coronavirus-gendergap-emergency/577942/.

Potter, Wendell. 2020. "Millions Of Americans Are About To Lose Their Health Insurance In A Pandemic| Wendell Potter". The Guardian. https://www.theguardian.com/commentisfree/2 $020 / \mathrm{mar} / 27 /$ coronavirus-pandemic-americanshealth-insurance.

Project Implicit. 2020. "Project Implicit". Implicit.Harvard.Edu. https://implicit.harvard.edu/implicit/.

Purdum, Todd. 2020. "Gavin Newsom's Nation-State". The Atlantic. https://www.theatlantic.com/politics/archive/2 020/04/coronavirus-california-gavinnewsom/610006/.
Rosenthal, Brian, Joseph Goldstein, Sharon Otterman, and Sheri Fink. 2020. "Why Surviving the Virus Might Come Down to Which Hospital Admits You". The New York Times. https://www.nytimes.com/2020/07/01/nyregio n/Coronavirus-hospitals.html

Roubein, Rachel and Sarah Owermohle. 2020. "U.S. lacks plan for getting vaccine to communities of color devastated by virus". Politico. https://www.politico.com/news/2020/08/03/v accine-minority-communities-389878

Twohey, Megan. 2020. "Who Gets a Vaccine First? U.S. Considers Race in Coronavirus Plans". The New York Times. https://www.nytimes.com/2020/07/09/us/coro navirus-vaccine.html

Weiler, Nicholas. 2020. "Inequality Fueled COVID-19 Transmission in San Francisco's Mission District, Says New Study". UCSF. https://www.ucsf.edu/news/2020/06/417881/i nequality-fueled-covid-19-transmission-sanfranciscos-mission-district-says

WHO. (2020). United States of America: WHO Coronavirus Disease (COVID-19) Dashboard. Retrieved July 24th 2020, from https://covid19.who.int/region/amro/country/u $\underline{\mathrm{S}}$

Yong, Ed. 2020. "How the Pandemic Defeated America". The Atlantic. https://www.theatlantic.com/magazine/archive 22020/09/coronavirus-americanfailure/614191/

Ans Irfan MD, MPH is a public health practitioner, researcher, and a faculty member at George Washington University with extensive expertise in equity, diversity, and inclusion. He is also a Robert Wood Johnson Foundation Health Policy Research Scholar. Some of his recent projects include: farmworkers health equity; the intersection of theology and public health; traffic wardens and climate adaptation in Pakistan; evaluation of physicians' training on climate change and health; global and occupational health equity. He can be contacted at ansirfan@gwu.edu.

Ankita Arora PhD, is a postdoctoral fellow at the University of Colorado- Anschutz Medical Campus. She studies the role and mechanism of RNA localization in neuronal cell lines. As an international scholar, she extensively advocates for promoting diversity and inclusion, especially in STEM.

Christopher Jackson is a PhD Candidate in Chemistry at the University of California, Berkeley, where his research focuses on developing nanomaterials tools for sensing and gene delivery in biological environments. 
Celina Valencia, DrPH, is a National Institutes of Health/National Cancer Institute T32 Postdoctoral Fellow in Cancer Disparities at the University of Arizona. Dr. Valencia's research focuses on cancer mortality disparities in rural populations.

\section{Acknowledgements}

Authors are grateful for the National Science Policy Network's DEI Committee for their leadership and creating the space to explore this idea.

\section{Disclaimer}

Authors have no conflicts of interest to disclose. This tertiary literature synthesis study not did not receive any funding from any sources. 